\title{
Intergenic ribosomal spacer variability in hexaploid oat cultivars and landraces
}

\author{
C. POLANCO+ \& M. PÉREZ DE LA VEGA* \\ Departamento de Genética, Facultad de Biología, Universidad de León, 24071 León, Spain
}

\begin{abstract}
The variability of the ribosomal DNA intergenic spacer (IGS) was analysed in 58 cultivars from a worldwide collection and 14 Spanish landraces of hexaploid oats. IGS sequences were amplified by the polymerase chain reaction using primers complementary to conserved sequences of the ribosomal genes. Twelve IGS length variants ranging from 4090 to $3210 \mathrm{bp}$ were observed; some are frequent and distributed worldwide whereas others seem to be restricted to Spanish landraces. Variability in length variant patterns among cultivars and landraces was extensive: a total of 28 different patterns was observed, which included two to six length variants. No variation was detected within cultivars except in six Spanish landraces. Length variants and patterns were unevenly distributed between bred cultivars, in which the longest were frequent, and landraces, in which some of the shortest were observed. No differentiation was found between spring and winter sown material. The possible relationship between IGS length variants and breeding and environmental adaptive responses, other than those related to the spring or winter habit, are discussed.
\end{abstract}

Keywords: Avena sativa, genetic variability, oats, rDNA, ribosomal intergenic spacer.

\section{Introduction}

Ribosomal RNA genes (rDNA) are tandemly repeated in large arrays or blocks which occur at one or more chromosome locations; usually each block is designated as a genetic locus. Two kinds of loci have been described in grass species: major loci associated with nucleolus organizing regions (Nor loci), made up of a high number of repeated gene units and clearly expressed, and minor loci made up of a low number of copies and only detected by hybridization techniques (Dubcovsky \& Dvorak, 1995). The basic organization of ribosomal DNA has been maintained in most eukaryotic systems. One repeating unit consists of the conserved $18 \mathrm{~S}, 5.8 \mathrm{~S}$ and $25 \mathrm{~S}$ rDNA coding regions and the corresponding internal spacers, and an intergenic spacer (IGS). IGS regions show a great variability in sequence and length between and also within species. Intraspecific IGS length variability is generally caused by different numbers of subrepeats which range in size from about $100 \mathrm{bp}$ to about $400 \mathrm{bp}$ for different plant species (Rogers \& Bendich, 1987). The intergenic ribosomal spacer is a complex regulatory unit

$\uparrow$ Present address: Department of Genetics, University of Leicester, Leicester LE1 7RH, U.K.

*Correspondence. E-mail: degmpv@unilcen.es and rDNA transcription regulatory sequences (polymerase binding, transcription enhancement and termination, etc.) are located in it and therefore could be of importance in gene expression (see Rogers \& Bendich, 1987; Clegg, 1990; Echeverría et al., 1994). Sometimes regulatory elements are included in subrepeats and it has been indicated that not only the subrepeat types but also their numbers and their methylation levels are important for transcription (Sardana et al., 1993). Thus, ribosomal intergenic spacer variability has been related to important biological and economic characteristics such as development rates in Drosophila (Cluster et al., 1987) or grain yield in maize (Rocheford et al., 1990).

Length variation in the plant rDNA intergenic spacer has been extensively studied For instance, Rogers \& Bendich (1987) listed 57 species belonging to 32 genera in which data on ribosomal spacer length were available. Recently, the structure of the IGS of hexaploid oat (Avena sativa L.) and the polymorphism of ribosomal DNA between Avena species has been reported (Jellen et al., 1994; Polanco \& Pérez de la Vega, 1994). The IGS of $A$. sativa contains five types of tandem subrepeats (named A to E) and three 'long' nonrepeated sequences in addition to short sequences interspaced between subrepeats. Subrepeat lengths were $\approx 90 \mathrm{bp}$ 
in $\mathrm{A}, 120 \mathrm{bp}$ in $\mathrm{B}, 150 \mathrm{bp}$ in $\mathrm{C}, 35 \mathrm{bp}$ in $\mathrm{D}$ and $160 \mathrm{bp}$ in $\mathrm{E}$, with minor length variation within each subrepeat family (Polanco \& Pérez de la Vega, 1994).

Population surveys of rDNA variation in crop plants and their wild relatives, usually observed as length polymorphisms by means of the RFLP method, have shown that variation in spacer length is common (Clegg, 1990). Ribosomal DNA variation at the population level can be caused by both heterogeneity among plants and/or heterogeneity within single plants. An individual plant can be heterogeneous with respect to rDNA (and other multicopy genes) because different length variants are: (1) located on different homologous chromosomes, i.e. heterozygosity, (2) associated with different loci or (3) present at the same loci (compound alleles). This complexity makes the precise analysis of rDNA variation difficult. Oat species are predominantly self-fertilizing, thus wild populations and landraces are usually made up of a mixture of several homozygous genotypes whereas cultivars are characterized by a single homozygous genotype (Singh et al., 1973; Allard et al., 1993; Pérez de la Vega et al., 1994). Therefore, although rDNA heterogeneity because of heterozygosity should be very low (Polanco \& Pérez de la Vega, 1995), heterogeneity caused by the presence of several loci should be common in polyploid oat species such as hexaploid oats in which three major NOR loci and a minor locus have been reported (Fominaya et al., 1995). However, a survey of ribosomal DNA polymorphism showed that geographically diverse $A$. sativa cultivars displayed little rDNA variation whereas $A$. byzantina displayed more extensive polymorphism (Jellen et al., 1994).

Interest in the genetic variability and genetic relationships among Avena sativa $\mathrm{L}$. landraces, breeding materials, ancestral and advanced cultivars and their implication in adaptedness and genetic improvement has increased recently, as demonstrated in several works ranging from quantitative character variability to isozyme and DNA polymorphisms (Souza \& Sorrells, 1991a,b; Lynch \& Frey, 1993; Moser \& Lee, 1994; O'Donoughue et al., 1994; Pérez de la Vega et al., 1994). In this work we present the results of a study on the rDNA spacer length polymorphism in 14 Spanish landraces and a worldwide collection of 58 cultivars of Avena sativa $\mathrm{L}$.

\section{Materials and methods}

All the materials used were described as Avena sativa $\mathrm{L}$. $(2 n=6 \mathrm{x}=42)$ by the donors of material.
However, $A$. sativa and $A$. byzantina are considered to be closely related and both have been hybridized extensively to obtain many oat cultivars (see Jellen $e t$ al., 1994). Thus, it is possible that some of our material is closer to the $A$. byzantina genetic background. Two sets of samples are distinguished: Spanish landraces (14) and a worldwide collection of cultivars (58). Cultivar names or genebank registration numbers and the institutions and genebanks who kindly provided the seed samples are indicated in Table 1. Genomic DNA was isolated from individual dry seeds and analysed separately. Initially, five seeds per landrace or cultivar (hereafter commonly designated as accessions) were analysed, although additional samples of five or 10 seeds were analysed from certain accessions. About $50 \mathrm{ng}$ of DNA from each seed was amplified using the 'touchdown' polymerase chain reaction (PCR) method (Don et al., 1991) and primers described by Polanco \& Pérez de la Vega (1994). An initial annealing temperature of $65^{\circ} \mathrm{C}$ was lowered by $1^{\circ} \mathrm{C}$ per cycle until $55^{\circ} \mathrm{C}$, and then maintained in 30 additional cycles. PCR amplification products were separated in $25 \mathrm{~cm}$ long, 1.5 per cent $(\mathrm{w} / \mathrm{v})$ agarose gels at $60 \mathrm{~V}$ in TAE buffer for $12 \mathrm{~h}$. Presence or absence and intensity (high, medium, and low) of bands in gels was observed after $1 \mu \mathrm{g} / \mathrm{mL}$ ethidium bromide staining, which was carried out by immersing and gently shaking the gels after DNA fractionation for $20 \mathrm{~min}$. Samples were randomized in and between gels, the cultivar Cometa was used as PCR positive control, and DNA fragments of the phage lambda at known concentration were also included in the gels. DNA concentration after PCR amplification was estimated by means of a GeneQuant (Pharmacia) spectrophotometer.

Similarities between accessions were estimated using Jaccard or Hedrick coefficients of similarity, and the resulting pairwise similarities were expressed as distance matrices. Jaccard similarity was used to compare uniform accessions. When band intensities were considered, present bands were coded as 111111,111110 or 111100 according to high, medium or low intensity, and absent bands were coded as 000000 . Hedrick similarity was used to compare all accessions, uniform and variable, and the frequency of each length variant in each accession was scored. Cluster analyses were conducted using the unweighted pair-group method (UPGMA) and the resulting clusters were expressed as dendrograms. Unrooted trees were obtained by the Fitch and Margolias method and the PHYLIP 3.5.c computer program (Felsenstein, 1993). In some comparisons sets of accessions were considered: the 
Table 1 Hexaploid oat material used

\begin{tabular}{|c|c|c|c|c|c|c|c|c|c|}
\hline \multicolumn{3}{|c|}{$\begin{array}{l}\text { Cultivar name or genebank } \\
\text { register number (abbreviation) }\end{array}$} & \multirow{2}{*}{$\begin{array}{c}\begin{array}{c}\text { rDNA } \\
\text { pattern }\end{array} \\
\mathrm{M}\end{array}$} & \multirow{2}{*}{$\begin{array}{l}\begin{array}{l}\text { Country of } \\
\text { origin }\end{array} \\
\text { Morocco }^{1}\end{array}$} & \multicolumn{2}{|c|}{$\begin{array}{l}\text { Cultivar name or genebank } \\
\text { register number (abbreviation) }\end{array}$} & \multirow{2}{*}{\multicolumn{2}{|c|}{$\begin{array}{cc} & \begin{array}{c}\text { rDNA } \\
\text { pattern }\end{array} \\
\mathrm{W} & \mathrm{U}\end{array}$}} & \multirow{2}{*}{$\begin{array}{l}\begin{array}{l}\text { Country of } \\
\text { origin }\end{array} \\
\text { KY, U.S.A. }\end{array}$} \\
\hline 320 & $(320)$ & W & & & KY 67-695 & (KY6) & & & \\
\hline 80.2 & $(802)$ & W & $S$ & Former USSR ${ }^{1}$ & La Previsión 13 & (LAP) & W & $\mathrm{A} 2$ & Argentina ${ }^{!}$ \\
\hline Ankara 76 & (ANK) & W & $\mathrm{Y}$ & Turkey $^{7}$ & Lidia & (LID) & $\mathrm{S}$ & $\mathrm{S}$ & Italy $^{6}$ \\
\hline Appaloosa & (APP) & $\mathrm{S}$ & A1 & WA, U.S.A. ${ }^{7}$ & Maldwyn & (MLD) & $S$ & I & Wales, U.K. ${ }^{1}$ \\
\hline Ardena Amarilla & (ARD) & $\mathrm{S}$ & I & Chile $^{1}$ & Manod & $(\mathrm{MAN})$ & $S$ & K & Wales, U.K. ${ }^{1}$ \\
\hline Argentina 345 & (ARG) & W & $\mathrm{T}$ & Argentina $^{1}$ & Milford & (MFD) & $S$ & V & Wales, U.K. ${ }^{1}$ \\
\hline Astro & (AST) & $S$ & $\mathrm{~T}$ & NY, U.S.A. ${ }^{7}$ & Montagnana & $(\mathrm{MON})$ & W & $\mathrm{T}$ & Italy $^{4}$ \\
\hline Benson & $(\mathrm{BEN})$ & $\mathrm{S}$ & $\mathrm{T}$ & MN, U.S.A. ${ }^{7}$ & $\mathrm{NC75-2}$ & (NC7) & W & $\mathrm{T}$ & NC, U.S.A. ${ }^{7}$ \\
\hline BG8421 & $(421)$ & W & * & Spain $^{2}$ & Okey & (OKE) & W & $\mathrm{U}$ & OK, U.S.A.? \\
\hline BG8431 & (431) & W & * & Spain $^{2}$ & Ombrone & (OMB) & W & $\mathrm{Y}$ & Italy $^{6}$ \\
\hline BG8434 & (434) & W & $\mathrm{E}$ & Spain ${ }^{2}$ & Ontana & (ONT) & $S$ & $\mathrm{~T}$ & ID, U.S.A. ${ }^{7}$ \\
\hline BG8444 & $(444)$ & W & $\mathrm{D}$ & Spain $^{2}$ & Orlik & (ORL) & $\mathrm{S}$ & $S$ & Czech Rep. ${ }^{10}$ \\
\hline BG8497 & (497) & W & G & Spain ${ }^{2}$ & PA $621-87$ & (PA6) & W & Y & PA, U.S.A. ${ }^{7}$ \\
\hline BG8498 & (498) & W & $\mathrm{J}$ & Spain $^{2}$ & Padarn & (PAD) & W & I & Wales, U.K. ${ }^{1}$ \\
\hline BG8507 & (507) & W & * & Spain $^{2}$ & Paramo & (PAR) & $\mathrm{S}$ & $\mathrm{W}$ & $\mathrm{Mexico}^{7}$ \\
\hline BG8575 & $(575)$ & W & * & Spain $^{2}$ & Platek & (PTK) & $S$ & I & Poland 5 \\
\hline BG8577 & $(577)$ & W & $\mathrm{C}$ & Spain $^{2}$ & Pluie d'Or & (PLU) & $S$ & $S$ & France $^{4}$ \\
\hline BG8583 & (583) & W & $*$ & Spain $^{2}$ & Powell JB 035 & (PWL) & W & $\mathbf{M}$ & Morocco $^{7}$ \\
\hline BG8590 & $(590)$ & W & $\mathrm{C}$ & Spain $^{2}$ & Powys & (POW) & W & I & Wales, U.K. ${ }^{1}$ \\
\hline BG8626 & $(626)$ & W & * & Spain $^{2}$ & Probsteier & (PRO) & $S$ & I & Denmark $^{1}$ \\
\hline BG8639 & $(639)$ & W & $\mathrm{P}$ & Spain $^{2}$ & Quinnoces & (QUI) & $S$ & $\mathrm{~F}$ & Portugal $^{3}$ \\
\hline BG8642 & $(642)$ & W & M & Spain $^{2}$ & RC 346 & (RC3) & $\mathrm{S}$ & I & Israel $^{1}$ \\
\hline Blackbutt & (BLA) & W & $\mathrm{Z}$ & Australia $^{7}$ & Risto & (RTO) & $S$ & $\mathbf{S}$ & Sweden ${ }^{8}$ \\
\hline Bob & (BOB) & $\mathrm{S}$ & $S$ & AR, U.S.A. ${ }^{7}$ & Rouge d'Algerie & (RDA) & W & $\mathrm{Y}$ & Algeria $^{4}$ \\
\hline Capa & (CAP) & $\mathbf{S}$ & I & Argentina $^{1}$ & S 147 & (S14) & W & $S$ & Wales, U.K. ${ }^{1}$ \\
\hline Cometa & (CTA) & $\mathbf{S}$ & I & Spain $^{9}$ & S 172 & (S17) & W & I & Wales, U.K. ${ }^{1}$ \\
\hline Condor & $(\mathrm{CON})$ & $\mathrm{S}$ & I & Netherlands $^{3}$ & Salem & (SAL) & W & I & NC, U.S.A. ${ }^{7}$ \\
\hline Cumberland & (CUM) & W & $\mathrm{U}$ & TN, U.S.A. ${ }^{7}$ & Santon & (SAN) & $S$ & $S$ & South Africa ${ }^{3}$ \\
\hline Dal & (DAL) & $\mathrm{S}$ & $\mathrm{S}$ & WI, U.S.A. ${ }^{7}$ & Sativa Krausei & (SKR) & $\mathrm{S}$ & $\mathrm{X}$ & $\operatorname{Iran}^{1}$ \\
\hline Emeline & (EME) & W & $S$ & France $^{4}$ & Taiko & (TAI) & $\mathrm{S}$ & I & New Zeland ${ }^{4}$ \\
\hline Ethiopia R439 & (ETH) & $\mathrm{S}$ & $S$ & Ethiopia $^{1}$ & Tam O-301 & (TAM) & W & I & TX, U.S.A. ${ }^{7}$ \\
\hline Firecracker & (FIR) & W & $\mathrm{R}$ & NC, U.S.A. ${ }^{4}$ & Tempo & (TEM) & $\mathrm{S}$ & I & Norway $^{8}$ \\
\hline Grey Winter & (GRW) & W & I & Wales, U.K. ${ }^{1}$ & Tripolis & (TRI) & $\mathrm{S}$ & I & Libya $^{3}$ \\
\hline Heros & (HER) & W & I & South Africa ${ }^{7}$ & Valko & (VAL) & $\mathrm{S}$ & $\mathrm{T}$ & Finland $^{8}$ \\
\hline Indian NP Hyb & (IND) & $S$ & M & India $^{1}$ & Windsor & (WIN) & $\mathrm{S}$ & K & VA, U.S.A. ${ }^{7}$ \\
\hline Keeper & (KEP) & $\mathrm{S}$ & $\mathrm{R}$ & England, U.K. ${ }^{1}$ & Winter Turf & (WTF) & W & I & Canada $^{1}$ \\
\hline
\end{tabular}

Sources of material: 1, AFRC Institute of Plant Science Research, Cambridge, United Kingdom; 2, Banco de Germoplasma, INIA, Spain; 3, Institut für Pflanzenbau und Pflanzenzüchtung (FAL), Braunschweig, Germany; 4, Institut National de la Recherche Agronomique, Le Magneraud, France; 5, Instytut Hodowli i Aklimatyzacji Roslin, Poland; 6, Istituto di Agronomia Generale e Cultivazioni Erbacee della Università di Pisa, Italy; 7, National Small Grain Collection, USDA-ARS, U.S.A.; 8, Nordic Gene Bank, Sweden; 9, Productores de Semillas S.A. (PRODES), Spain; 10 , Zentralinstitut für Genetik und Kulturpflanzenforschung, Gatersleben, Germany.

*Variable accessions; w, Winter accessions; s, Spring accessions.

Spanish landraces from the Spanish Genebank (14 accessions) on one side, and the world collection (58 accessions), or subsets of them on the other (i.e. Mediterranean accessions, possible 'old' cultivars).

\section{Results}

The analysis of five seeds per accession showed differences in the IGS band pattern, either in band presence-absence or in band intensity, between accessions but no difference within accessions, with the exception of six Spanish landraces, in which an average of four bands were variable (presenceabsence) out of the eight bands present in these six landraces altogether. Subsequently, five additional seeds from each Spanish landrace and from each of 
16 accessions of the world collection were analysed. This second set of seeds confirmed the existence of differences in band (length variant) presenceabsence within some Spanish landraces and the uniformity of cultivars from the world collection. Sets of five additional seeds from six of the 16 previous cultivars confirmed the pattern uniformity within cultivars.

A total of 12 bands (= IGS length variants) were observed. Their lengths in bp were approximately 4090, 4010, 3970, 3920, 3850, 3800, 3730, 3610, 3570, 3450,3410 and 3210 (Fig. 1). These length variants are arranged from left to right in Table 2 and numbered 1-12 in Fig. 2. Band distribution among oat plants was uneven. For instance, whereas length variants 3730 and 3850 were present in most plants, some others were infrequent; band 4090 was infrequent among Spanish landraces but relatively frequent among plants of the world collection; the shorter variant, 3210, was observed only in accessions from the Iberian Peninsula, in Spanish landraces and in the Portuguese accession Quinnoces (Fig. 1). Thus, some length variants are distributed worldwide in most plants and cultivars whereas others are restricted in their distribution to the Spanish collection and/or to some cultivars of the world collection. According to the length of subrepeats in the spacer, the different IGS length variants can be conveniently explained by differences in the number of B, D or E subrepeats (Fig. 1). The most frequent and worldwide distributed length variants $(4090,3970,3850$ and 3730) and variant 3610 observed in Spanish materials may differ from each other by the length of one B subrepeat, and so do variant 3920 from 3800 , variant 3570 from 3450, or two Bs such as 3450 from 3210 . Differences between
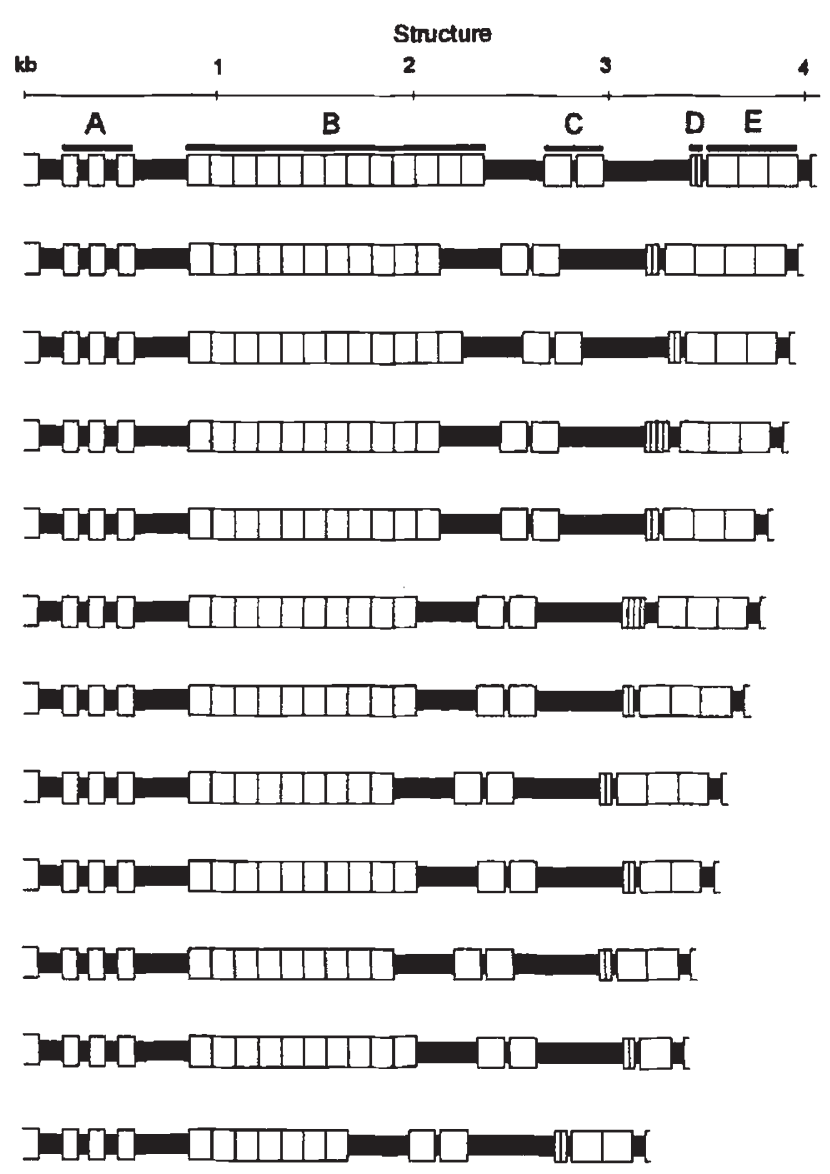

\begin{tabular}{|c|c|c|c|}
\hline \multirow{2}{*}{$\begin{array}{l}\text { Longth } \\
\text { (base pairs) }\end{array}$} & \multicolumn{3}{|c|}{ Porcentages } \\
\hline & Spanish landraces & World collection & Total \\
\hline \multirow[t]{2}{*}{4090} & 6.35 & 79.31 & 56.73 \\
\hline & 28.57 & 79.31 & 69.44 \\
\hline \multirow[t]{2}{*}{4010} & 0.00 & 17.24 & 12.02 \\
\hline & 0.00 & 17.24 & 13.89 \\
\hline \multirow[t]{2}{*}{3970} & 41.27 & 48.28 & 46.15 \\
\hline & 57.14 & 48.28 & 50.00 \\
\hline \multirow[t]{2}{*}{3920} & 22.22 & 0.00 & 6.73 \\
\hline & 35.71 & 0.00 & 6.94 \\
\hline \multirow[t]{2}{*}{3850} & 99.21 & 94.83 & 96.15 \\
\hline & 100.00 & 94.83 & 95.83 \\
\hline \multirow[t]{2}{*}{3800} & 38.89 & 0.00 & 11.78 \\
\hline & 50.00 & 0.00 & 9.72 \\
\hline \multirow[t]{2}{*}{3730} & 91.27 & 82.76 & 85.34 \\
\hline & 100.00 & 82.76 & 86.11 \\
\hline \multirow[t]{2}{*}{3610} & 5.56 & 0.00 & 1.68 \\
\hline & 7.14 & 0.00 & 1.39 \\
\hline \multirow[t]{2}{*}{3570} & 7.14 & 5.17 & 5.77 \\
\hline & 14.28 & 5.17 & 6.94 \\
\hline \multirow[t]{2}{*}{3450} & 6.35 & 3.45 & 4.33 \\
\hline & 7.14 & 3.45 & 4.16 \\
\hline \multirow[t]{2}{*}{3410} & 6.35 & 0.00 & 1.92 \\
\hline & 21.43 & 0.00 & 4.16 \\
\hline \multirow[t]{2}{*}{3210} & 27.78 & 1.72 & 9.61 \\
\hline & $\mathbf{5 7 . 1 4}$ & 1.72 & 12.50 \\
\hline & 126 & 290 & 416 \\
\hline lumbe & 14 & 58 & 72 \\
\hline
\end{tabular}

Fig. 1 Deduced structure and observed frequencies of ribosomal length variants in hexaploid oats. A to $\mathrm{E}$ indicate the different subrepeats. Percentages of plants or accessions in which each length variant was observed are indicated in upper and lower rows, respectively. 
Table 2 IGS length variant patterns and their distribution among plants and accessions of hexaploid oats

\begin{tabular}{|c|c|c|c|c|c|c|c|}
\hline \multirow[b]{2}{*}{ Pattern } & & \multicolumn{3}{|c|}{ Number of plants } & \multicolumn{3}{|c|}{ Number of accessions } \\
\hline & & S. 1. & W. W. & Total & S. 1 . & W. W. & Total \\
\hline D & 000111100000 & 10 & 0 & 10 & 1 & 0 & 1 \\
\hline $\mathrm{C}$ & 000011100000 & 24 & 0 & 24 & 4 & 0 & 4 \\
\hline $\mathrm{E}$ & 000110100000 & 9 & 0 & 9 & 1 & 0 & 1 \\
\hline M & 000010100000 & 19 & 15 & 34 & 4 & 3 & 7 \\
\hline I & 101010100000 & 6 & 95 & 101 & 3 & 19 & 20 \\
\hline $\mathrm{R}$ & 101010000000 & 0 & 10 & 10 & 0 & 2 & 2 \\
\hline $\mathrm{S}$ & 100010100000 & 0 & 55 & 55 & 0 & 11 & 11 \\
\hline $\mathrm{T}$ & 110010100000 & 0 & 35 & 35 & 0 & 7 & 7 \\
\hline $\mathrm{U}$ & 110010000000 & 0 & 15 & 15 & 0 & 3 & 3 \\
\hline V & 100010000000 & 0 & 5 & 5 & 0 & 1 & 1 \\
\hline W & 100000100000 & 0 & 5 & 5 & 0 & 1 & 1 \\
\hline $\mathrm{X}$ & 101000100000 & 0 & 5 & 5 & 0 & 1 & 1 \\
\hline $\mathrm{Y}$ & 001010000000 & 0 & 20 & 20 & 0 & 4 & 4 \\
\hline $\mathrm{K}$ & 001010100000 & 7 & 10 & 17 & 2 & 2 & 4 \\
\hline G & 001010110001 & 7 & 0 & 7 & 1 & 0 & 1 \\
\hline $\mathbf{J}$ & 001010100001 & 10 & 0 & 10 & 1 & 0 & 1 \\
\hline $\mathrm{F}$ & 000010100001 & 1 & 5 & 6 & 1 & 1 & 2 \\
\hline$P$ & 001010101101 & 8 & 0 & 8 & 1 & 0 & 1 \\
\hline $\mathrm{Z}$ & 000000101100 & 0 & 5 & 5 & 0 & 1 & 1 \\
\hline $\mathrm{A} 1$ & 100010101100 & 0 & 5 & 5 & 0 & 1 & 1 \\
\hline $\mathrm{A} 2$ & 000010101000 & 0 & 5 & 5 & 0 & 1 & 1 \\
\hline A & 001010100011 & 6 & 0 & 6 & 2 & 0 & 2 \\
\hline B & 100111000000 & 2 & 0 & 2 & 1 & 0 & 1 \\
\hline $\mathrm{H}$ & 001110000000 & 1 & 0 & 1 & 1 & 0 & 1 \\
\hline $\mathrm{L}$ & 000010100011 & 2 & 0 & 2 & 1 & 0 & 1 \\
\hline $\mathrm{N}$ & 000011000000 & 7 & 0 & 7 & 3 & 0 & 3 \\
\hline $\mathrm{O}$ & 001000001001 & 1 & 0 & 1 & 1 & 0 & 1 \\
\hline Q & 001111100000 & 6 & 0 & 6 & 1 & 0 & 1 \\
\hline Total & & 126 & 290 & 416 & & & \\
\hline
\end{tabular}

Length variants are arranged from left to right in decreasing length; $1=$ presence, $0=$ absence. Patterns are grouped according Fig. 2 clusters. The bottom group includes patterns only observed in variable Spanish accessions and not included in Fig. 2 and Table 1.

S. l., Spanish landraces; W. W., worldwide collection.

these sets and the remaining variants can be explained by the addition of an E subrepeat or two D subrepeats.

On the basis of band presence-absence, a total of 28 banding patterns was observed. Pattern distribution was highly uneven, with only four patterns being shared by the cultivars and the Spanish landraces (Table 2). The number of IGS variants present in patterns ranged from two to six, but the most frequent patterns showed three or four bands. The two most frequent variants, 3850 and 3730 (5th and 7th from left in Table 2), were present simultaneously in $\approx 81$ per cent of plants and 90 per cent of accessions. Patterns including these two variants together with variant 3970 represent $\approx 37$ per cent of plants and 46 per cent of accessions. The most common pattern, designated I, included these three variants together with the largest variant, 4090. This largest variant is infrequent in Spanish landraces (it is also infrequent in other 'primitive' cultivars, as will be further discussed) and so banding patterns including it are also infrequent in Spain (Table 2). Length variants 4090, 3970, 3850 and 3730 (bands 1 , 3,5 , and 7 in pattern order) seem to be the basic set of variants because all the patterns have at least one and all except three patterns ( $\mathrm{N}, \mathrm{O}$ and $\mathrm{Z}$ ) have at 


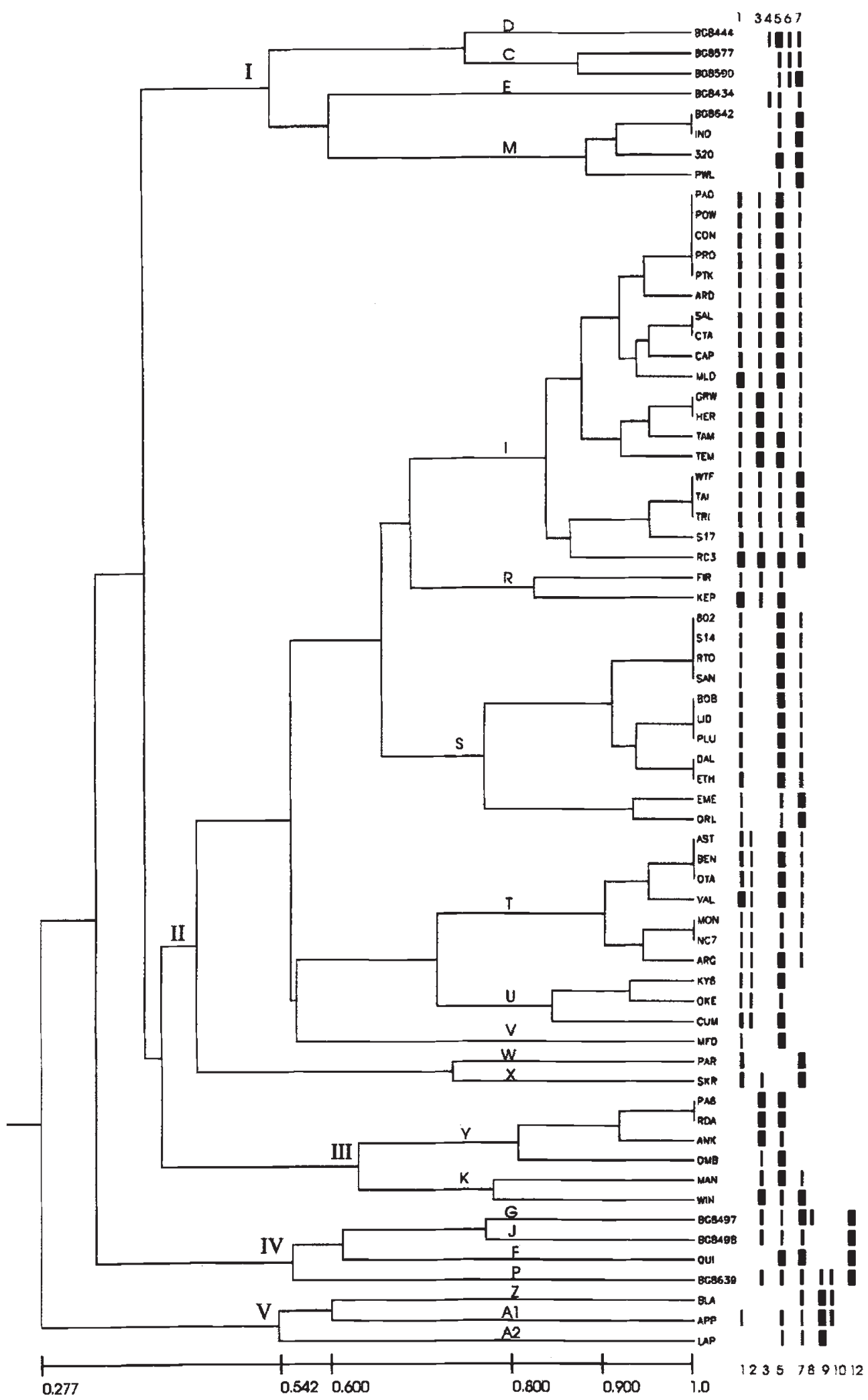

Fig. 2 Phenogram obtained using the UPGMA method and Jaccard similarity considering band intensity. IGS length variant patterns are represented on the right, variants are ordered in decreasing length from left to right. Letters indicate the designation of patterns considering only the presence-absence of variants. Roman numbers designate clusters in the phenogram. 
least two of these variants. No association was observed between ribosomal IGS patterns and the spring or winter habit (Table 1, Fig. 2). The result of the UPGMA showed clustering of uniform accessions using Jaccard similarities when band intensities are considered. Some characteristic clusters can be distinguished: two including medium size variants (I and III), cluster II which includes all the accessions with the largest variant (4090 bp) except Appaloosa (pattern A1), cluster IV with the Iberian accessions including the shortest variant (3210 bp), and finally the heterogeneous cluster V. Clusters I, II and IV were almost unchanged when band intensities were not considered and either Jaccard or Hedrick similarities were used (data not shown).

In order to analyse the relationships among IGS patterns, unrooted trees were constructed using Jaccard and Hedrick indices, neglecting band intensities (Fig. 3). Using the Jaccard index, all 28 patterns were compared. When the Hedrick index was used the frequency of each length variant was scored in variable accessions and in one of the uniform accessions representing each banding pattern. Both trees show a similar topology, where patterns $\mathrm{M}$ and $\mathrm{K}$ (with only the two or three most frequent and widely distributed length variants) are near a central radiating node, and patterns forming each branch are almost identical and resemble the clusters described in the dendrogram of Fig. 2. It can also be seen that the patterns exclusively observed among Iberian accessions (Spanish landraces and the Portuguese cultivar Quinnoces) are mainly included in two branches in both trees.

\section{Discussion}

The IGS variability in oat accessions agrees with previous data on isozyme variability. Whereas Spanish landraces show high levels of isozyme genetic variability (Gómez et al., 1991), hexaploid oat bred cultivars are usually monomorphic, or nearly so, even for the most polymorphic plant isozyme systems, as has already been pointed out in a classic paper (Singh et al., 1973).

Hexaploid oat ribosomal spacer length variants seem to be characteristic of different kinds of acces-
Fig. 3 Unrooted trees obtained comparing Jaccard distances among the different IGS patterns (a) or Hedrick distances among an accession from each pattern and variable accessions (b). In (a), codes refer to IGS patterns and asterisks denote the patterns observed only in Spain. In (b), codes refer to the accessions selected as representative of an IGS pattern (in parentheses) and asterisks denote the majority pattern in Spanish variable accessions; $(\mathrm{I} / \mathrm{N})$ means that these two patterns were equally frequent in the BG8626 accession.

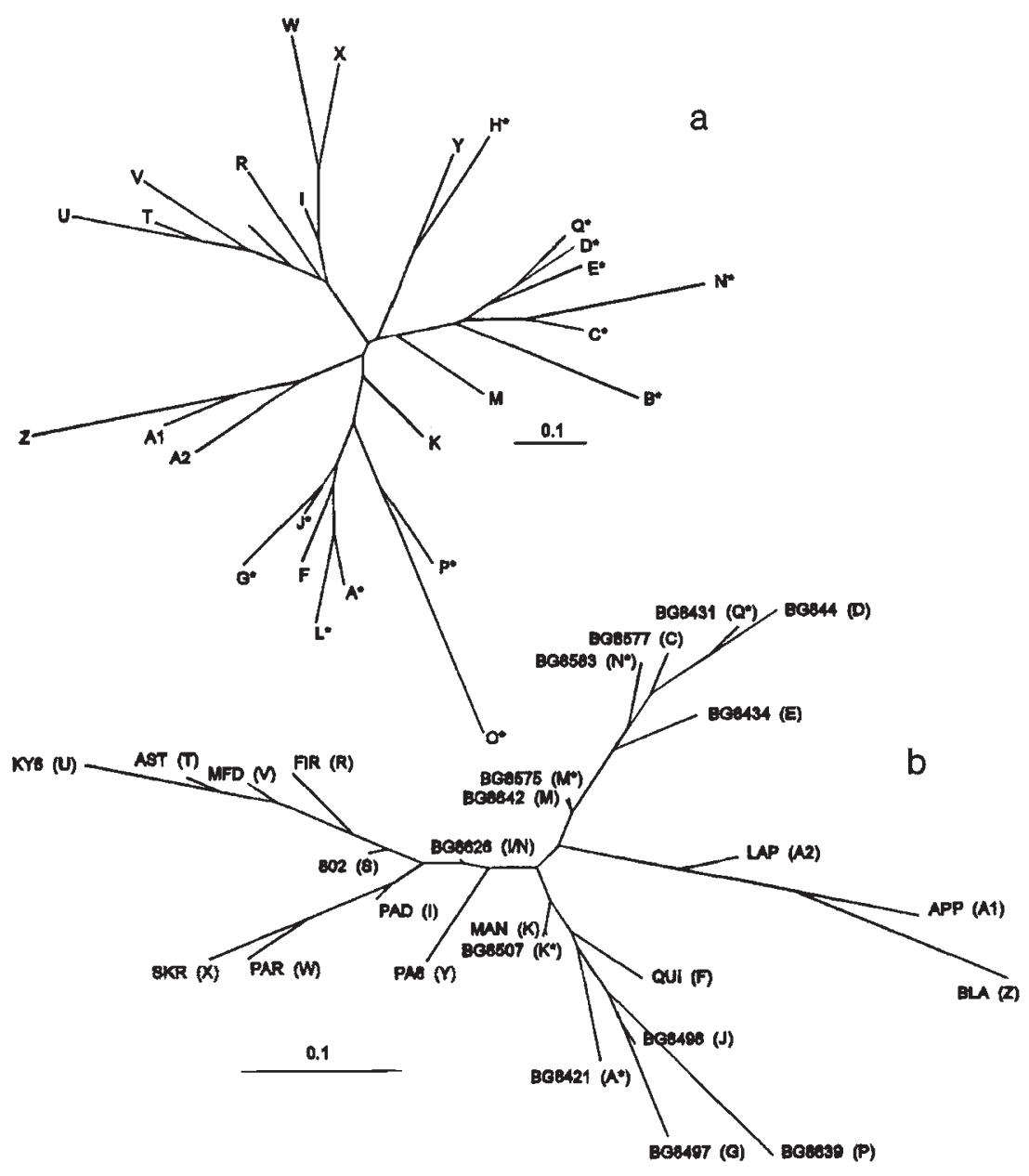


sions; whereas the longest ones are relatively frequent among bred cultivars, the shortest ones are characteristic of landraces and 'old' cultivars. In particular, the longest one is rare in Spanish landraces (it is present only in 6.35 per cent of plants), whereas it is highly frequent among bred cultivars. For instance, it is present in 14 out of 16 cultivars from the USA and Canada and eight out of nine from the United Kingdom. The second longest variant was observed in seven of the USA cultivars in addition to a single cultivar from each of Argentina, Finland and Italy. On the other hand, the two shortest variants were observed only in Spanish landraces and in the Portuguese cultivar Quinnoces. Climatic factors can also play a role in the distribution of length variants; when the frequency of variants common to the Spanish landrace set and the worldwide set, and several subsets from the latter were compared, the Spanish landraces were found to be similar only to the 'old' Mediterranean cultivar set. Patterns observed in landraces and 'old' cultivars seem to be closely related and quite distinct from most of the patterns observed in bred cultivars. In unrooted trees (Fig. 3), patterns K (variants 3970, 3850 and 3730 ) and $\mathbf{M}$ (variants 3850 and 3730 ) are located near the radiation point, which suggests a possible original kind of pattern from which other patterns could have originated. IGS variability has been related to important breeding aspects such as grain yield in maize (Rocheford et al., 1990), and with the adaptation to environmental factors in Hordeum and Avena species (Saghai-Maroof et al., 1990; Cluster \& Allard, 1995). Thus, it is possible that some IGS patterns in hexaploid oats are related to breeding and/or environmental adaptive responses, other than adaptations to the spring or winter habit, because most variants and patterns are shared by both kinds of cultivars (Table 1 and Fig. 2). On the other hand, most spring and winter oat cultivars are discriminated into separate clusters when several other DNA markers are used (O'Donoughue et al., 1994).

The analysis of rDNA variability, to date almost exclusively carried out by RFLP techniques, is somewhat difficult owing to some of its genetic particularities such as the frequent presence of several rDNA loci, the possible sequence heterogeneity in and between loci, the variable number of rDNA repeats per rDNA locus, and the homogenization among rDNA repeats (see Dubcovsky \& Dvorak, 1995; and references therein). In our analysis of hexaploid oats the majority of plants showed four-banded patterns (38.46 per cent) closely followed in frequency by three-banded patterns (36.78 per cent). Two-banded patterns were observed in 17.07 per cent of plants, whereas 7.71 per cent showed more than four bands. This result agrees with the variability observed in wild diploid and tetraploid oat species by RFLP analysis using radioactive and nonradioactive probes (Cluster \& Allard, 1995; Polanco \& Pérez de la Vega, 1995), but contrasts with the RFLP results obtained by Jellen et al. (1994). The latter study reports that 14 out of 15 accessions of geographically diverse $A$. sativa showed two constant variants of $2.6+7.5$ and $10.5 \mathrm{~kb}$, produced by the presence $(2.6+7.5)$ or absence (the total 10.5 length of the rDNA repeat) of an EcoRI site in the IGS, whereas $A$. byzantina accessions showed two or three variants (the same two as $A$. sativa and some additional IGS size variants). According to the IGS sequence (Polanco \& Pérez de la Vega, 1994) and the restriction map (Jellen et al., 1994), the position of the variable EcoRI site should be located just upstream of the B subrepeats, and hence upstream of most of the possible variable subrepeats. Therefore, most of the IGS variability must be included, and probably undetected, in the longest fragments of about $7.5 \mathrm{~kb}$ (which includes most of both the transcribed and the spacer rDNA) and $10.5 \mathrm{~kb}$ (the whole rDNA repeat). Another possible explanation for the higher polymorphism observed by PCR than by RFLP could be the amplification to an observable level in gels of IGS copies in the minor locus which are undetectable by some RFLP or in situ procedures. This point raises the question as to whether all minor variants can be amplified by PCR to detection level and all minor loci can be easily detected by in situ hybridization because, for instance, minor sites vary in having between 5 and 100 copies (Leitch \& Heslop-Harrison, 1992) in barley. In fact, whereas only three major rDNA loci were reported by in situ hybridization of radioactive probes (Jellen et al., 1994), an additional minor locus was detected by fluorescence in situ hybridization (Fominaya et al., 1995).

In this study we have used a PCR amplification technique using primers complementary to internal conserved ribosomal sequences (Polanco \& Pérez de la Vega, 1994). This method has proved to be useful in the analysis of the IGS oat variability: each pattern was repeatable in band number, position and relative intensity. It is worth mentioning that, in addition to the sample size of 15 seeds analysed in several cultivars, Cometa seeds have been used as standard in other experiments and they always showed the same pattern. It can be observed (Fig. 2) that there is no correlation between the length of each variant and its intensity; for instance, in I 
patterns where length variants $4090,3970,3850$ and 3730 are present, any of the variants can show high, medium or low intensity (copy number) depending upon the cultivar. Thus, it seems that, at least for oat IGS, PCR amplification does not depend as much upon the length of the sequence as upon the relative number of original copies characteristic of each cultivar genotype.

\section{Acknowledgements}

We are grateful to all the Institutions and Genebanks who supplied us with the oat samples and to Dr M. A. Jobling for his suggestions regarding this manuscript. This work was supported by a research grant (PB88-0415) and a doctoral grant (to C. Polanco) from the Spanish D.G.I.C.Y.T.

\section{References}

ALlARD, R. W., GARCIA, P., SAENZ DE MIERA, L. E. AND PÉREZ DE LA VEGA, M. 1993. Evolution of multilocus genetic structure in Avena hirtula and Avena barbata. Genetics, 135, 1125-1139.

CLEGG, M. T. 1990. Molecular diversity in plant populations. In: Brown, A. H. D., Clegg, M. T., Kahler, A. L. and Weir B. S. (eds) Plant Population Genetics, Breeding, and Genetic Resources, pp. 98-115. Sinauer, Sunderland, MA.

ClUSTER, P. D. AND ALLARD, R. W. 1995. Evolution of ribosomal DNA (rDNA) genetic structure in colonial Californian populations of Avena barbata. Genetics, 139, 941-954.

CLUSTER, P. D., MARINKOVIC, D., ALLARD, R. W. AND AYALA, F. J. 1987. Correlations between development rates, enzyme activities, ribosomal DNA spacer-length phenotypes, and adaptation in Drosophila melanogaster. Proc. Natl. Acad. Sci. U.S.A., 84, 610-614.

DON, R. H., COX, E. T., WAINWRIGHT, B. J., BAKER, K. AND MATTICK, J. s. 1991. 'Touchdown' PCR to circumvent spurious priming during gene amplification. Nucl. Acids Res., 19, 4008.

DUBCOVSKY, J. AND DVORAK, J. 1995. Ribosomal RNA multigene loci: nomads of the Triticeae genomes. Genetics, 140, 1367-1377.

ECheVerría, M., PENON, P. ANd DElseny, M. 1994. Plant ribosomal DNA external spacer binding factors: a novel protein binds specifically to a sequence close to the primary pre-rRNA processing site. Mol. Gen. Genet., 243, 442-452.

FELSENSTEIN, J. 1993. PHYLIP, phylogeny inference package. Version 3.5.c. Department of Genetics, University of Washington, Seattle.

FOMINAYA, A., HUEROS, G., LOARCE, Y. AND FERRER, E. 1995. Chromosomal distribution of a repeated DNA sequence from $\mathrm{C}$-genome heterochromatin and the identification of a new ribosomal DNA locus in the Avena genus. Genome, 38, 548-557.
GómEZ, C., SAENZ DE MierA, L. E. AND PÉREZ DE LA VEGA, M. 1991. Estimation of the isozymatic genetic variability of a Spanish Avena sativa germplasm collection. $\mathrm{Pl}$. Breed., 106, 293-300.

JEllen, E. N., PHILlips, R. L. AND RINES, H. W. 1994. Chromosomal localization and polymorphisms of ribosomal DNA in oat (Avena spp.). Genome, 37, 23-32.

LEITCH, I. J. AND HeSlop-haRRison, J. S. 1992. Physical mapping of the $18 \mathrm{~S}-5.8 \mathrm{~S}-26 \mathrm{~S}$ rRNA genes in barley by in situ hybridization. Genome, 35, 1013-1018.

LYNCH, P. J. AND FREY, K. J. 1993. Genetic improvement in agronomic and physiological traits of oat since 1914. Crop Sci., 33, 984-988.

MOSER, H. AND LEE, M. 1994. RFLP variation and genealogical distance, multivariate distance, heterosis, and genetic variance in oats. Theor. Appl. Genet., 87, 947-956.

o'donoughue, L. S., SOUZA, E., TANKSley, S. D. AND SORRELls, M. E. 1994. Relationships among North American oat cultivars based on restriction fragment length polymorphisms. Crop Sci., 34, 1251-1258.

PÉREZ DE LA VEGA, M., SAENZ DE MIERA, L. E. AND ALlARD, R. W. 1994. Ecogeographical distribution and differential adaptedness of multilocus allelic associations in Spanish Avena sativa L. Theor. Appl. Genet., 88, 56-64.

POlANCO, C. AND PÉREZ DE la VEGA, M. 1994. The structure of the rDNA intergenic spacer of Avena sativa L.: a comparative study. Plant Mol. Biol., 25, 751-756.

POlANCO, C. AND PÉREZ DE LA VEGA, M. 1995. Length polymorphism in the ribosomal DNA intergenic spacer of rye and slender wild oats. J. Hered., 86, 402-407.

ROGERS, s. O. AND BENDICH, A. J, 1987. Ribosomal RNA genes in plants: variability in copy number and in the intergenic spacer. Plant Mol. Biol., 9, 509-520.

ROCHEFORD, T. R., OSTERMAN, J. C. AND GADNER, C. O. 1990. Variation in the ribosomal DNA intergenic spacer of a maize population mass-selected for high grain yield. Theor. Appl. Genet., 79, 793-800.

SAGHAl MAROOF, M., ALlARD, R. W. AND ZHANG, Q. 1990. Genetic diversity and ecogeographical differentiation among ribosomal DNA alleles in wild and cultivated barley. Proc. Natl. Acad. Sci. U.S.A., 87, 8486-8490.

SARdana, R., O'DEll, M. AND Flavell, R. 1993. Correlation between the size of the intergenic regulatory region, the status of cytosine methylation of rRNA genes and nucleolar expression in wheat. Mol. Gen. Genet., 236, 155-162.

SINGH, R. S., JAIN, S. K. AND QUALSET, C. O. 1973. Protein electrophoresis as an aid to oat variety identification. Euphytica, 22, 98-105.

SOUZA, E. AND SORRElls, M. E. 1991a. Relationships among 70 North American oat germplasms: I. Cluster analysis using quantitative characters. Crop Sci., 31, 599-605.

SOUZA, E. AND SORRELls, M. E. 1991b. Relationships among 70 North American oat germplasms: II. Cluster analysis using qualitative characters. Crop Sci., 31, 605-612. 